UDC $541.49+546.562$

\title{
Co(II), Ni(II), Cu(II) COMPLEXES \\ WITH 1-NICOTINOIL-2-(2-HYDROXYBENZYL) HYDRAZINE
}

\author{
P.A.Fatullayeva \\ M.Nagiyev Institute of Catalysis and Inorganic Chemistry, NAS of Azerbaijan \\ pfatullayeva@mail.ru \\ Received 17.07.2019
}

\begin{abstract}
By reduction of 1-nicotinoyl-(2-salicylidene)hydrazone with use $\mathrm{NaBH}_{4}$ 1-nicotinoyl-2-(2-hydroxybenzyl)hydrazine was obtained. $\mathrm{Co}(\mathrm{II}), \mathrm{Ni}(\mathrm{II}), \mathrm{Cu}$ (II) complexes with these ligands were synthesized and their structure was studied. It was shown that first ligand behaves as a dianionic tridentate, while second is monoanionic tridentate.
\end{abstract}

Keywords: hydrazides hydrazones, nicotinic acid, metal complexes $\mathrm{Co}(\mathrm{II}), \mathrm{Ni}(\mathrm{II}), \mathrm{Cu}(\mathrm{II})$.

doi.org/10.32737/0005-2531-2019-4-27-31

\section{Introduction}

Metal complexes with nicotinoylhydrazone-o-hydroxyaryl- aldehydes exhibit antioxidant, antimicrobial [1], antituberculosis activity [2], have catalytic activity in the alcohols oxidation [3], epoxidation of olefins [4] and catalyze the reaction of benzoyl chloride with arylboronic acid to form fluorenons [5] ].

Nicotinoilsalicylidenehydrazides are potentially dianionic tetradentate ligands, therefore they are capable to forming various mono-, bi- and polynuclear structures with metal ions.

In the present of time, mononuclear oxoand dioxovanadium complexes [6, 7], mono-, binuclear dioxomolybdenum complexes [3, 7, 8], polynuclear zinc complexes [9], mononuclear complexes of $\mathrm{V}(\mathrm{IV}), \mathrm{Mn}(\mathrm{III}), \mathrm{Ni}(\mathrm{II}), \mathrm{Cu}$ (II) [1], $\mathrm{Ag}(\mathrm{I})$ [10], $\mathrm{Fe}(\mathrm{III})$ [11], $\mathrm{Pb}$ (II) [12] and $\mathrm{Pd}(\mathrm{II})$ are known [5].

Almost in all these complexes, 1-nicotinoyl-2-salicylidenehydrazone behaves as a tridentate and mono- or dianionic (depending on the nature of the metal ion) ligand. It is noteworthy, that in most cases the pyridine nitrogen atom does not participate in coordination, however, in some cases it enters into coordination with neighboring metal atoms, forming polymeric structures [9].

An analysis of the literature has shown, that so far there have been no publications in the literature on metal complexes with hydrazones, reduced on the azomethine bond. At the same time, such ligands can be of interest due to their flexible structure. In this work, we obtained 1-nicotinoy-1 -2 (2-hydroxybenzyl)hydrazine, $\mathrm{Co}(\mathrm{II}), \mathrm{Ni}$ (II), $\mathrm{Cu}$ (II) complexes with this ligand and studied their structure and properties.

\section{Experimental part}

Nicotinoylhydrazide bought from the firm "Sigma Aldrich"

1-nicotinoyl-(2-salicylidene)hydrazone (I). $10^{-3} \mathrm{~mol}(0.137 \mathrm{~g})$ of nicotinoilhydrazide was dissolved in $15 \mathrm{ml}$ of dioxane and there solution of $10^{-3} \mathrm{~mol}(0.122 \mathrm{~g})$ of salicylic aldehyde in $10 \mathrm{ml}$ methanole was added. The mixture was stirred jn the magnetic stirrer at $40^{\circ} \mathrm{C}$ for 20 minutes. After cooling the solution bright yellow Schiff base I crystals precipitated, which were filtered and dried, m.p. $=222^{0} \mathrm{C}$.

$\mathrm{Cu}(\mathrm{II})$ complex with ligand 1-nicotinoyl(2-salicylidene)hydrazone (I). $10^{-3} \mathrm{~mol}(0.241 \mathrm{~g})$ of the hydrazone (I) was dissolved in $10 \mathrm{ml}$ of dioxane, and there a solution of $10^{-3} \mathrm{~mol}(0.199 \mathrm{~g})$ of copper(II) acetate in $10 \mathrm{ml}$ of water was added. The mixture was heated at $50^{\circ} \mathrm{C}$ for $20 \mathrm{~min}$, then the solution was filtered. After cooling dark green crystals with a melting point $>250^{\circ} \mathrm{C}$ dropped out.

The $\mathrm{Co}(\mathrm{II})$ and $\mathrm{Ni}(\mathrm{II})$ complexes were obtained similarly.

Reduction of 1-nicotinoyl-(2-salicylidene)hydrazone (I). $0.1 \mathrm{~mol}$ of 1-nicotinoyl-2-salicylidene) hydrazone was suspended in $40 \mathrm{ml}$ of methanol and there added in small portions of $0.15 \mathrm{~mol}$ of sodium borohydride with at intensive stirring. After adding the whole amount of $\mathrm{NaBH}_{4}$, stirring was continued for 0.5 hour, then the colorless solution was diluted three times with water and acidified with a solution of $\mathrm{HCl}(\sim 10 \%)$ to $\mathrm{pH} \sim 7.5$. The dropped out substance was separated on a porous filter, washed by water, dried and recrystallized from mixture ethanol-water 1:1. After drying under vacuum, $T_{\text {melt }}>250^{\circ} \mathrm{C}$. 
$\mathrm{Cu}$ (II) complex with 1-nicotinoyl-2-(2hydroxybenzyl) hydrazine (II). $10^{-3} \mathrm{~mol}(0.243 \mathrm{~g})$ 1-nicotinoyl-2-(2-hydroxybenzyl)hydrazine(II), dissolved in $30 \mathrm{ml}$ of ethanol, mixed with a methanol solution of $1 \cdot 10^{-3} \mathrm{~mol}(0.199 \mathrm{~g})$ of $\mathrm{Cu}$ $\left(\mathrm{CH}_{3} \mathrm{COO}\right)_{2} \cdot \mathrm{H}_{2} \mathrm{O}$. After some time, dark blue small crystals dropped out, which was separated and dried. The melting point is $>250^{\circ} \mathrm{C}$.

Calculated\% C 49.38, H 4.12, O 17.56, $\mathrm{N}$ 11.52, $\mathrm{Cu}$ 17.42. $\mathrm{C}_{15} \mathrm{H}_{15} \mathrm{O}_{4} \mathrm{~N}_{3} \mathrm{Cu}$.

Found, \%: C 49.40, H 4.17, O 17.46, N 11.59, $\mathrm{Cu} 17.32$.

The $\mathrm{Co}(\mathrm{II})$ and $\mathrm{Ni}(\mathrm{II})$ complexes were obtained similarly to the copper complex with using cobalt and nickel tetrahydrate acetate.

Calculated, \% : C 50.09, H 4.17, O 17.78, $\mathrm{N}$ 11.67, Co 16.37( $\left.\mathrm{C}_{15} \mathrm{H}_{15} \mathrm{O}_{4} \mathrm{~N}_{3} \mathrm{Co}\right)$.

Found, \% : C 50.08, H 4.19, O 17.83, N 11.71, Co 16.42.

Calculated,\%: C 50.04, H 4.17, O 17.79, $\mathrm{N}$ 11.68, Ni 16.3. $\mathrm{C}_{15} \mathrm{H}_{15} \mathrm{O}_{4} \mathrm{~N}_{3} \mathrm{Ni}$.

Found, \%: C 50.08, H 4.12, O 17.81, N 11.70, Ni 16.45.

A fine crystalline precipitate of brown and green color, respectively, precipitated from the resulting solutions, which were separated and dried in vacuum.

\section{Results and discussion}

We have synthesized for the first time1nicotinoyl-2-(2-hydroxybenzyl)hydrazine (II) by reducing of 1-nicotinoyl-(2-salicylidene)hydrazone (I) with using sodium borohydride and its complexes with $\mathrm{Co}(\mathrm{II}), \mathrm{Ni}(\mathrm{II}), \mathrm{Cu}(\mathrm{II})$. For comparison the $\mathrm{Co}(\mathrm{II}), \mathrm{Ni}(\mathrm{II}), \mathrm{Cu}(\mathrm{II})$ complexes without reduced ligand I were received and studied.

The IR spectrum the reduced hydrazone(II) (Figure 1) contains an intense absorption band at $3360 \mathrm{~cm}^{-1}$, related to stretching vibrations of $\mathrm{N}-\mathrm{H}$ and also band of vibrations of amide carbonyl group at $1662 \mathrm{~cm}^{-1}$. The absorption band at $1620 \mathrm{~cm}^{-1}$, which is observed in the Schiff base I, is absent in the reduced ligand II. It should be noted the absence in the IR spectrum of the Schiff base of the absorption band of the carbonyl amide group at $\approx 1660 \mathrm{~cm}^{-1}$, which undoubtedly is result of strong shift of keto-enol equilibrium towards the formation of the enol form (compound $\mathrm{I} b$ ):

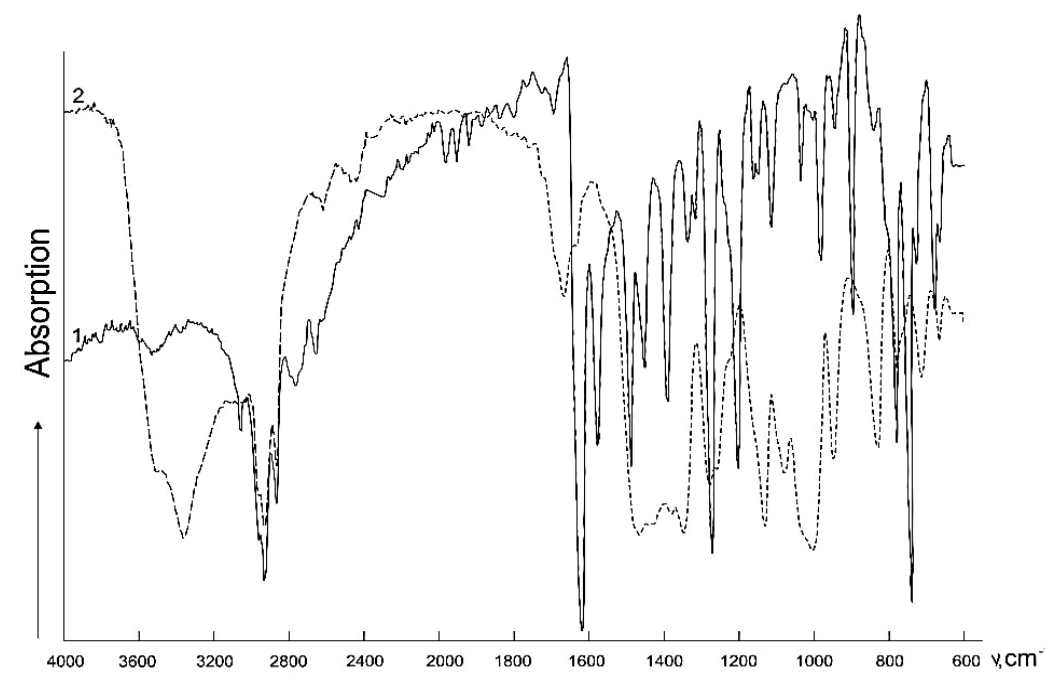

Fig.1. IR spectra 1-nicotinoyl-(2-salicylidene)hydrazone (I) and 1-nicotinoyl-2-(2hydroxybenzyl) hydrazine (II) (dashed line).
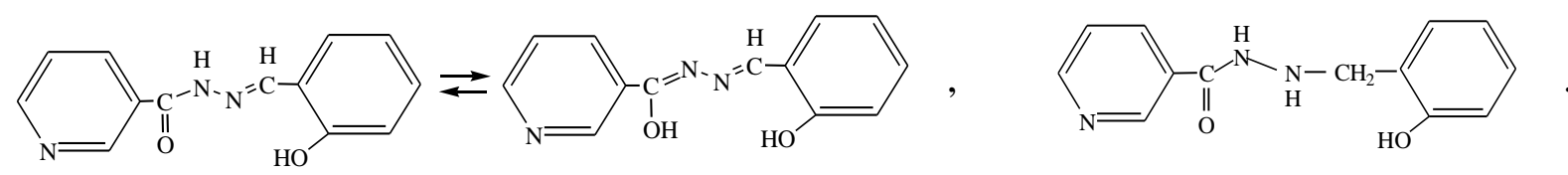

$a$ 
Electronic absorption spectra of hydrazine I and reduced hydrazone II (Figure 2) confirm the predominant presence of the enol form in compound I. The long-wavelength absorption band at $360 \mathrm{~nm}$ in compound I can be attributed to the $\mathrm{C}=\mathrm{N}-\mathrm{N}=\mathrm{C}$ fragment, conjugated with aromatic rings and the band at $300 \mathrm{~nm}-$ to absorption due to aromatic rings. In the reduced compound II, the absorption band of the aromatic rings is shifted to the shortwave region and is observed at $280 \mathrm{~nm}$.

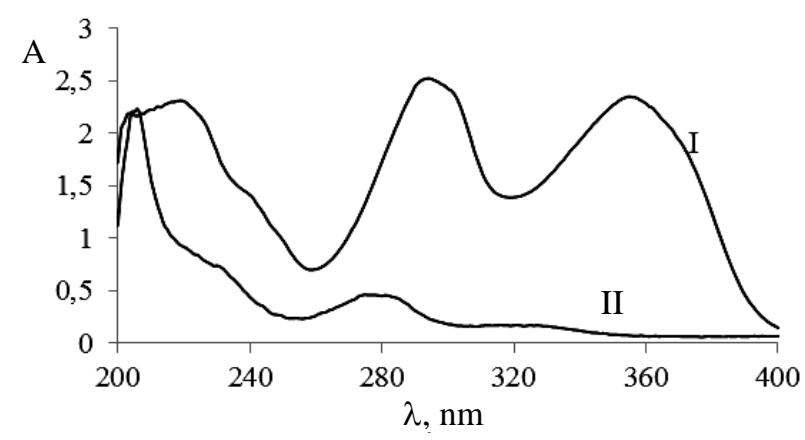

Fig. 2. Electronic absorption spectra of compounds I and II in ethanol.

The IR spectra of metal complexes ( $\mathrm{Cu}(\mathrm{II}), \mathrm{Co}(\mathrm{II})$ and $\mathrm{Ni}(\mathrm{II})$ ) with hydrazine I contain the absorption band of the azomethine group at $1615-1630 \mathrm{~cm}^{-1}$ and do not contain the absorption band of amide carbonyl at $\approx 1660 \mathrm{~cm}^{-1}$. This confirms his participation in coordination with the metal ion in the enolic form. There is also an absorption peak at $3400 \mathrm{~cm}^{-1}$ related to coordinated water.

Thus, the data of elemental analysis and IR spectroscopy suggest the following structure for metal complexes with ligand I (structure III).

In the IR spectra of a nickel (II) complex with a reduced ligand II, the amide carbonyl band observed in the starting ligand at $1666 \mathrm{~cm}^{-1}$ shifts towards lower frequencies. The presence of this band and its shift during complexation indicate its participation in coordination in the keto-form. This, in turn, is evidence that the ligand in this case is monoanionic. In addition, the IR spectrum of this complex contains absorption bands of the carboxylate group at 1580 and $1420 \mathrm{~cm}^{-1}$.
The obtained date allows us to accept the structure (IV) for these complexes.

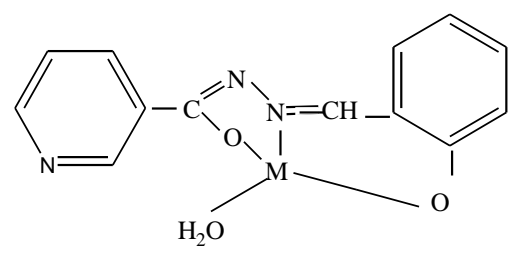

III

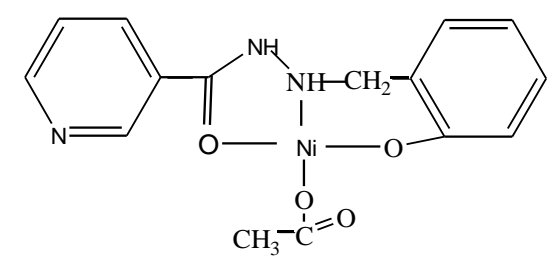

IV

$$
\mathrm{M}=\mathrm{Co}(\mathrm{II}), \mathrm{Ni}(\mathrm{II}), \mathrm{Cu}(\mathrm{II})
$$

Thus, it has been shown that nicotinoylhydrazone of salicylic aldehyde can be reduced to the corresponding nicotinoil 2-hydroxybenzyl hydrazide. Studies have also shown the different nature of coordination of 1-nicotinoyl-2salicylidenehydrazone and its reduced analogue 1-nicotinoyl-2-(2-hydroxybenzyl)hydrazine. If in the first case the ligand behaves as dianionic tridentate, in the second case it is monoanionic tridentate.

A number of works are known in which it has been shown that carbohydrate hydrazides, hydrazones carboxylic acids possess bactericidal and fungicidal properties $[1,2]$.

However, hydrazones and their complexes reduced by the azomethine group have not been studied yet in this respect. We have shown the bactericidal and fungicidal properties of 1-nicotinoyl-2-(2-hydroxybenzyl)hydrazine (II) and its Co(II) complex (see table).

It can been seen from table, that 1-nicotinoyl-2-(2-hydroxybenzyl)hydrazine (II) showed the high fungicidal and bactericidal activity. The Co(II) complex showed only bactericidal activity. 
Antimicrobial properties of 1-nicotinoyl-2-(2-hydroxybenzyl) hydrazine (II) and its Co(II) complex

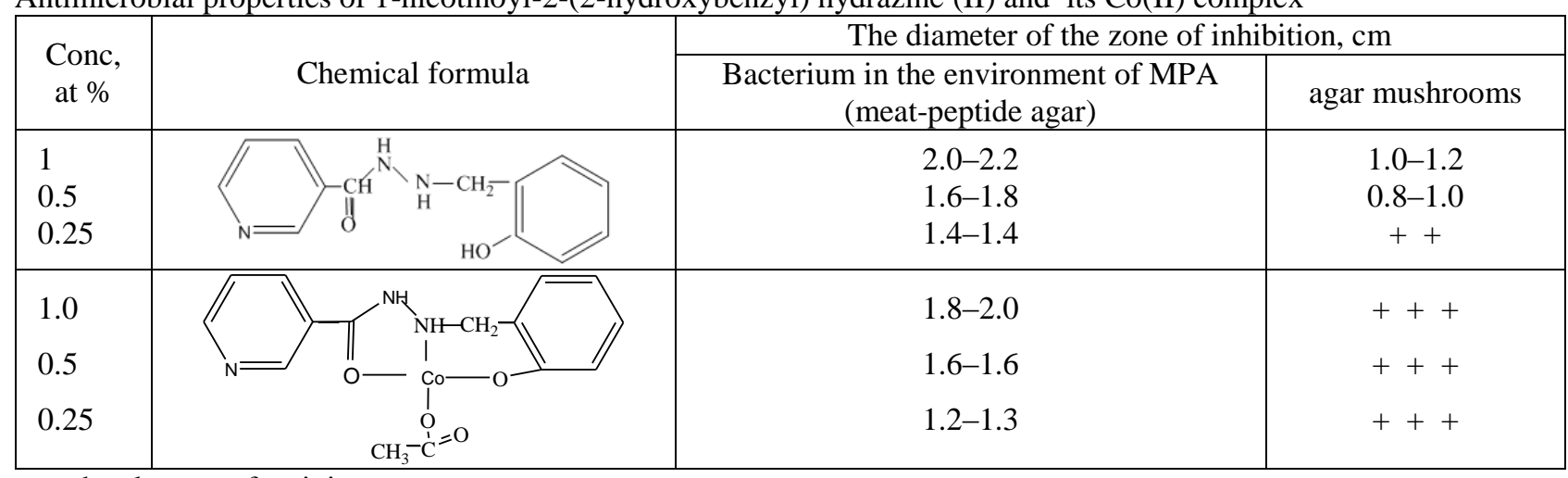

+- the absence of activity

\section{References}

1. Hussain M., Shafiq Z., Hussain A., Yaqub M., Arshad S., Ashraf M., Abbasi B.H., Ahmad H.B. Synthesis and Antioxidant and Antibacterial Activities of Metal-Based Schiff Bases of Nicotino, Isonicotinoyl and Benzoyl Hydrazides. Asian J. Chem. 2013. V. 25. No 5. P. 52593-2596. http: dx.doi.org/10.14233/ajchem.2013.13495.

2. Kehinde Olurotimi Ogunniran, Micheal Adediran Mesubi, K. V. S. N. Raju. Tadigoppula Narender Structural and in vitro anti-tubercular activity study of (E)-N'-(2,6-dihydroxybenzylidene)nicotinohydrazide and some transitionmetal complexes. Iran Chem. Soc. DOI 10.1007 / s13738-014-0544-1.

3. Mannar R. Maurya, Sarita Dhakaa, Fernando Avecilla Oxidation of the secondary alcohols by conventional and microwave-assisted methods using the donor ligands. Avecillab New J. Chem. 2015. V. 39. P. 2130-2139. DOI: 10.1039/ C4NJ02208D.

4. Mannar R. Maurya, ReshuTomar, LataRana and Fernando Avecilla. Trinuclear Dioxidomolybdenum(VI) Complexes of Tritopic Phloroglucinol based ligands and their Catalytic Applications for the Selective Epoxidation of Olefins. Eur. J. Inorganic Chem. DOI: 10.1002 / ejic.201800440.

5. Arumugam Vignesh, Werner Kaminskyand Nallasamy Dharmaraj. Expeditious Assembly of Fluorenones through DominoReactions of Benzoyl Chlorides with ArylboronicAcidsCatalyzed by ONO Pincer-like Palladium(II) Complexes.Chem. Cat. Chem. 2016. V. 8 P. 3207-3212 DOI: 10.1002/cctc.201600717.

6. Sunshine D. Kurbaha, M. Asthanab, IbanphyllaSyiemlieha, Alzelia, A. Lywaita, M. Longchara, R. A. Lala. New types of complexes with hydrazineligands: Syntheses, crystal structure and their catalytic application toward $\mathrm{C}-\mathrm{H}$ bond functionalization. DOI: 10.1016 / j.jorganchem.2018. 08.025
7. Gui-hua sheng, Xiao han, Yu-ting ye, Jin-qi ren, Zhong-lu you, and Hai-liangzhu. Synthesis, Characterization, and Crystal Structures of NewOxovanadium(V) Complexes With Mixed Nicotinohydrazoneand 8-Hydroxyquinoline Ligands. Synthesis and Reactivity in Inorganic, Metal-Organic, and Nano-Metal Chemistry 2016. V. 46. P. 1129-1132 DOI: 10.1080 / 15533174.2015.1004432

8. Nancy Mathew, M.R. PrathapachandraKurup. Synthesis and characterization of Mo(VI) complexes derived from ONO donoracylhydrazones. Spectrochim. Acta Part A 78 2011. P. 1424-1428 https: doi.org/10.1016/j.saa.2011.01.021.

9. Fabio Borbone, Ugo Caruso, Simona Concilio, Shiran Nabha, Barbara Panunzi, Stefano Piotto, Rafi Shikler, Angela Tuzi. Mono-, Di-, and Polymeric Pyridinoylhydrazone ZnII Complexes: Structure and Photoluminescent Properties. Eur. J. Inorg. Chem. 2016. P. 818-825 https: doi.org/10.1002/ejic.201501132.

10. Repich H.H., Orysyk S.I., Orysyk V.V., Zborovskii Yu.L., Pekhnyo V.I., Vovk M.V. Synthesis, crystal structure and spectral characterization of the first Ag complex compounds, O-N, O-coordinated Nacylhydrazones of salicylaldehyde. J. Molecular Structure 1144 2017. P. 225-236. https: doi.org/10.1016/j.molstruc. 2017.05.024.

11. Jian-Xin Yu, Vikram D. Kodibagkar, Rami R. Hallac, Li Liu, and Ralph P. Mason. Dual 19F / ${ }^{1}$ HNMR Generator for In Vivo Detection of $\beta$ Galactosidase | Bioconjugate Chem. 2012. V. 23. P. 596-603. DOI 10.1021 / bc200647q.

12. AgataTrzesowska-Kruszynska. On the construction of lead coordination polymers derived from $\mathrm{N}^{\prime}-(2-$ hydroxybenzylidene)nicotinohydrazide via covalent andnon-covalent interactions J. Coordination Chemi. 2014. V. 67. No 1. P. 120-135. https: doi.org/10.1080/00958972.2013.876494. 


\section{1-NIKOTINOILL-2-(2-HIDDROKSIBENZIL)HIDRAZINIIN Co(II), Ni(II), Cu(II) KOMPLEKSLəRİ}

\section{P.A.Fatullayeva}

1-nikotinoil-2(caliciliden)hidrazonun(I) $\mathrm{NaBH}_{4}$ vasitəci ilə reduksiyasi yolu ilə 1-nikotinoil-2-hidroksibenzil)hidrazin alınmışdir. $\mathrm{Bu}$ liqandla $\mathrm{Co}(\mathrm{II}), \mathrm{Ni}(\mathrm{II}), \mathrm{Cu}(\mathrm{II})$ kompleksləri sintez olunmuş və onların quruluşu öyrənilmişdir. Göstərilmişdir ki, 1-nikotinoil-2-(caliciliden) hidrazon (I) özünü dianion tridentat liqand kimi, 1-nikotinoil-2-(2hidroksibenzil)hidrazin(II) özunu monoanion tridentat liqand kimi aparır.

Açar sözlar: nikotin turşusunun hidrazidlari, hidrazonların reduksiyası, metal komplekslari.

\section{КОМПЛЕКСЫ Сo(II), Ni(II), Cu(II) C 1-НИКОТИНОИЛ-2-(2-ГИДРОКСИБЕНЗИЛ) ГИДРАЗИНА}

\section{П.А.Фатуллаева}

Восстановлением 1-никотиноил-(2-салицилиден)гидразона с помощью $\mathrm{NaBH}_{4}$ получен 1-никотиноил-2-(2гидроксибензил)гидразин. Синтезированы комплексы $\mathrm{Co}(\mathrm{II}), \mathrm{Ni}(\mathrm{II}), \mathrm{Cu}(\mathrm{II})$ с этими лигандами и изучено их строение. Показано, что первый ведет себя как дианионный тридентатный, в то время как второй - моноанионный тридентатный лиганд.

Ключевые слова: гидразиды никотиновой кислоты, восстановление гидразонов, комплексы металлов. 